\title{
OBITUARIES
}

\section{Professor H. W. F. Saggs, BD, MTh, MA, PhD, FSA (1920-2005)}

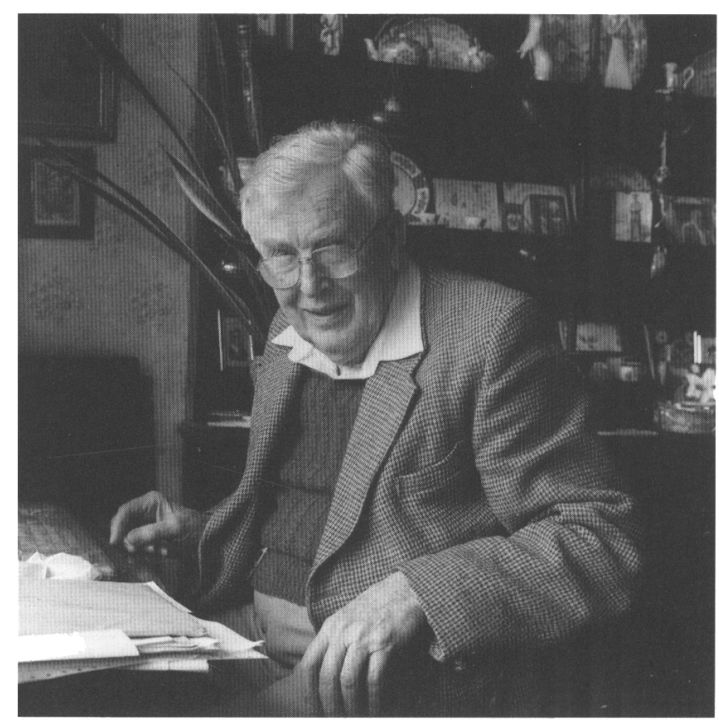

Harry Saggs studied Assyriology under Sidney Smith at the School of Oriental and African Studies, London, after serving with the Fleet Air Arm during World War II. His interest in the subject had been kindled while taking a degree in Theology at King's College, London, prior to the War. As a Scarborough Student he joined the British School of Archaeology in Iraq's excavations at Nimrud for the 1952 season. There Max Mallowan invited him to publish the archive of 243 letters found during that season, a task which occupied him for the following decades, resulting in a series of articles in Iraq and culminating in The Nimrud Letters 1952 (Cuneiform Texts from Nimrud V), published by the School in 2001. He also served as epigraphist during the second season of the School's excavations at Tell al-Rimah in 1965 and published the tablets found during that season in Iraq in 1968. He served as a member of the School's Council for many years and was always ready to support its activities.

Saggs taught at the School of Oriental and African Studies from 1953 until 1966 when he was appointed to the Chair of Semitic Languages at University College, Cardiff. Students from several countries benefited from his clear and careful teaching. Helping Iraqi colleagues and students took an important place in his life. Besides supervising their doctoral studies in Britain, he taught on several occasions in Baghdad and Mosul universities. All remember his modesty, his kindness and his consistency.

His range of scholarship is evident in his 1976 Jordan Lectures, The Encounter with the Divine in Mesopotamia and Israel (1978), in which he contested widely held opinions, particularly among Old Testament scholars. He developed an apologia for the "calculated frightfulness" commonly considered a characteristic of the Assyrians, pointing to the far worse barbarisms of the twentieth century. A much larger audience continues to benefit from the less technical books he wrote: The Greatness that was Babylon (1962, revised 1988), Everyday Life in Assyria and Babylonia (1965), The Might that was Assyria (1984), Civilization before Greece and Rome (1989) and The Babylonians (1995).

Harry Saggs found especial enjoyment in exploring northern Iraq, ancient Assyria, with his wife Joan, to whom we express our heartfelt sympathy.*

Alan Millard

\footnotetext{
* The Editors wish to thank Mr Joseph Ford for permission to reproduce his photograph of his grandfather.
} 